\title{
Heavy metals in wetland soils along a wetland-forming chronosequence in the Yellow River Delta of China: levels, sources and toxic risks
}

Guangliang Zhang ${ }^{1}$, Junhong Bai ${ }^{*, 1}$, Qingqing Zhao, Qiongqiong Lu, Jia Jia, Xiaojun Wen State Key Laboratory of Water Environment Simulation, Beijing Normal University, Beijing 100875, P.R. China

Abstract: Surface soil $(0-20 \mathrm{~cm})$ samples were collected from four chronological sequences of wetlands (i.e., >50-yr-old wetlands, 40-yr-old wetlands, 30-yr-old wetlands and 10-yr-old wetlands) in the Yellow River Delta of China in May and June of 2007. Total contents of Al, As, $\mathrm{Cd}, \mathrm{Cr}, \mathrm{Cu}, \mathrm{Ni}, \mathrm{Pb}$ and $\mathrm{Zn}$ were determined using inductively coupled plasma atomic absorption spectrometry (ICP-AAS) to investigate the levels, sources and toxic risks of heavy metals in these wetlands. Our results showed an increasing trend for $\mathrm{Pb}, \mathrm{Cu}$ and $\mathrm{Zn}$ along the wetland-forming chronosequence although their pollution levels were low. Both As and Cd exhibited significant enrichment due to their high enrichment factor $(\mathrm{EF})$ values $(\mathrm{EF}>5)$, especially in older wetlands (i.e., >50-yr-old and 40-yr-old wetlands), whereas other heavy metals were minimally or moderately enriched in this region. The results of principal component analysis showed that $83.09 \%$ of total variance based on eigenvalues (eigenvalue>1) could be explained by three principal components (PCs) in four wetlands. The source of $\mathrm{Al}, \mathrm{Cu}, \mathrm{Pb}$ and $\mathrm{Zn}$ was different from $\mathrm{Cd}, \mathrm{Cr}$ and Ni. According to the sediment quality guidelines (SQGs) of China, soil samples in the younger wetlands, especially the 10-yr-old wetlands, were moderately polluted by $\mathrm{As}, \mathrm{Cd}$ and $\mathrm{Ni}$. According to the SQGs of US EPA, all soil samples were heavily polluted by As and moderately

\footnotetext{
${ }^{*}$ Corresponding author. Tel.: +86 01058802029.E-mail address: Baijh@126.com (J. Bai).

${ }^{1}$ These authors contributed equally to this work and should be considered co-first authors. 1
} 
polluted by $\mathrm{Ni}$ and soil samples in the older wetlands were moderately polluted by Cr. However, with the exception of As and $\mathrm{Ni}$, the contents of other heavy metals in the four wetlands did not exceed the probable effect level (PEL) values. As, $\mathrm{Cd}$ and $\mathrm{Ni}$ were identified as heavy metals of primary concerns in four wetlands, $\mathrm{Cr}$ were of moderate concern in older wetlands, and $\mathrm{Pb}, \mathrm{Cu}$ and $\mathrm{Zn}$ should be paid more attention in younger wetland (i.e., 10-yr-old and 30-yr-old wetlands). A new and sensitive toxic risk index (TRI) is developed for the accurate assessment of toxic risk for heavy metals in wetland soils compared with the sum of the toxic units ( $\sum \mathrm{TUs}$ ), and $\mathrm{As}, \mathrm{Cr}, \mathrm{Ni}$ and Cd showed higher contributions to TRI.

Keywords: Heavy metals; Enrichment factor (EF); Pollution levels; Sediment quality guidelines (SQGs); Toxic units (TUs); Toxic risk index (TRI)

\section{Introduction}

Heavy metals pollution has caused increasing concerns all over the world because heavy metals are easily bioaccumulated through food chains even at low contents in the environment (Kennish, 1992; Pejman et al., 2015) and then pose a serious threat to human health, other living organisms and natural ecosystems (Lu et al., 2014; Yu et al., 2014; Zhang et al., 2009; Deforest et al., 2007; Maanan et al., 2015). Heavy metals in soil have been considered to be powerful tracers for monitoring the impacts of human activities (Guo et al., 2012) because heavy metal pollution in the environment mainly derived from anthropogenic sources(Yu et al., 2014).

As a result of the complex interaction between fluvial and marine processes, coastal wetlands often act as a main sink for heavy metals bonded in the sediment and soil (Sun et al., 2015; Bai et al., 2011a; Williams et al., 1994). With the accumulation of heavy metals, coastal wetlands may 
gradually become a potential source of heavy metals since heavy metals can also be released from soil/sediment in the changing environment (Xie et al., 2014). Up to now, a large number of researches on heavy metals in estuarine and coastal wetlands have been conducted in larger deltas such as the Yellow River Delta (Sun et al., 2015; Bai et al., 2012), the Yangtze River Delta (Hu et al., 2015; Hu et al., 2013; Gorenc et al., 2004) , the Pearl River Delta (Xiao et al., 2012; Zhang et al., 2010; Li et al., 2007), the Mekong River Delta (Cenci and Martin, 2004), the Amazon River Delta (Vital and Stattegger, 2000) and the Mississippi River Delta (Grabowski et al., 2001) and so on. Many researches have focused on the bioaccumulation (Sun et al., 2015; Zhang et al., 2010), the spatial and temporal variations (Lu et al., 2014; Hu et al., 2013; Gorenc et al., 2004; Bai et al., 2014), the fate (Cenci and Martin, 2004) and the ecological risks (Long et al., 2000) of heavy metals, and the effects of anthropogenic activities on their enrichment levels (Wang et al., 2014; Hu et al., 2015), however, little information is available on the heavy metals pollution levels in wetland soils with different forming ages in the coastal zones due to wetland expansion.

The Yellow River Delta (YRD) is one of the most rapid sedimentation areas on earth (Zhou et al., 2015) due to the large amount of sediment inputs from upstream to its estuary each year. It is estimated that approximately $1.05 \times 10^{7} \mathrm{t}$ of sand and soil per year are carried and deposited in the delta (Xu et al., 2002), with a rate of more than $20 \mathrm{~km}^{2}$ of additional valuable land per year (Zong et al., 2009). In addition, the Yellow River has changed its course more than ten times since 1855 (Ye et al., 2015), which resulted in the creation of more than $2500 \mathrm{~km}^{2}$ of new wetlands during a period of less than 150 years ( $\mathrm{Li}$ and Chen, 2003). Although the heavy metal pollution is less serious in the YRD than in the above-mentioned larger deltas (Bai et al., 2012), heavy metals have shown an increasing tendency in the YRD in the last decade as a result of intensive human 
activities, e.g., sediment movements resulting from the flow-sediment regulation of Xiaoliangdi Reservoir, the rapid development of petrol oil industries and irrigated agriculture around this delta (Nie et al., 2010; Bai et al., 2012). Therefore, the YRD become an ideal area to investigate heavy metal levels in wetland soils with different ages. The primary objectives of this study were: (1) to investigate heavy metal levels and their enrichment degrees in soil from four wetlands with different ages; (2) to identify the possible sources using multivariate analysis (Principal component analysis and Correlation analysis); (3) to assess the pollution levels and ecotoxic risks of these heavy metals using sediment quality guidelines (SQGs) ,the sum of the toxic units ( $\sum$ TUs) and a new toxic risk index (TRI).

\section{Materials and Methods}

\subsection{Study area}

The study area is located in the Yellow River Delta $\left(37^{\circ} 10^{\prime}-38^{\circ} 40^{\prime} \mathrm{N}\right.$ and $118^{\circ} 30^{\prime}-120^{\circ} 10^{\prime} \mathrm{E}$,

Fig.1), Shandong province, China. It has a warm-temperate and continental monsoon climate, with annual mean precipitation of $640 \mathrm{~mm}$ and annual mean evaporation of $1962 \mathrm{~mm}$. The annual mean air temperature is $11.9{ }^{\circ} \mathrm{C}$, with 196 frostless days (Bai et al, 2015). Soil type in this region is typical Fluvisols, originating from the sediment and the parent materials of loess soil (Huang et al., 2012). The dominant vegetation primarily comprises Phragmites australis, Suaeda salus, Tamarix chinensis, Imperata cylindrica and Salix metsudana.

In the past 50-60 years, the Yellow River shifted artificially several times. In 1964, the Yellow River shifted artificially from its Shenxiangou course to the Diaokouhe course, and then shifted artificially from the Diaokouhe course to the Qingshuigou course in 1976 to prevent the flow path sway from sandy deposition (Zhou et al., 2015). In 1996, a minor shift moved the river 
mouth northeastward to the present site (Q8 course), leaving the Qingshuigou river mouth abandoned (Yang et al., 2011). Therefore, the study area could be divided into four types of wetlands (i.e., >50-yr-old, 40-yr-old, 30-yr-old and 10-yr-old wetlands) based on the wetland-forming chronosequence. These wetlands in the YRD has being suffered from degradation threat over the years (Liu and Qi, 2011) due to natural threats (e.g., marine and coastal erosion, sea-level rise, seawater intrusion, and droughts) and intensive human activities (e.g., flow-sediment regulation, agricultural and industrial discharge, and coastal reclamation) (Bai et al., 2012; Huang et al., 2012 ).

\subsection{Sample collection and analysis}

Surface soil $(0-20 \mathrm{~cm})$ samples were collected from each of four wetlands and in total 35 soil samples were obtained from four wetlands, including fifteen samples in the $>50$-yr-old wetlands, seven samples in the 40-yr-old wetlands, eight samples in the 30-yr-old wetlands and five samples in the 10-yr-old wetlands.. All soil samples were placed in polyethylene bags and brought to the laboratory and then air dried at room temperature for three weeks. All of the air-dried soil samples were sieved through a 2-mm nylon sieve to remove coarse debris and stones, and then ground with a pestle and mortar until all particles passed a 0.149-mm nylon sieve for the determination of soil chemical properties.

Soil samples were digested with an $\mathrm{HClO}_{4}-\mathrm{HNO}_{3}-\mathrm{HF}$ mixture in Teflon tubes to determine the contents of total sulfur (TS), total phosphorous (TP), $\mathrm{Al}, \mathrm{As}, \mathrm{Cd}, \mathrm{Cr}, \mathrm{Cu}, \mathrm{Ni}, \mathrm{Pb}$ and $\mathrm{Zn}$. The digested solutions of soil samples were analyzed using the inductively coupled plasma atomic absorption spectrometry (ICP-AAS). Quality assurance and quality control were assessed using duplicates, method blanks and standard reference materials (GBW07401) from the Chinese 
Academy of Measurement Sciences with each batch of samples (1 blank and 1 standard for each 10 samples). The recoveries of samples spiked with standards ranged from $95 \%$ to $106 \%$. Soil organic matter (SOM) was determined using the method of Walkley and Black (1934). Available phosphorus (AP) was determined using the Mo-Sb colorimetric method. Soil $\mathrm{pH}$ was measured using a Hach pH meter (Hach Company, Loveland, CO, USA) (soil:water = 1:5).

\subsection{Enrichment factor (EF)}

Enrichment factor (EF) was selected to assess the pollution level and the possible anthropogenic impact of each of the observed heavy metals (Bai et al., 2014; Selvaraj et al., 2004). In order to calculate the $\mathrm{EF}$ values, $\mathrm{Al}, \mathrm{Fe}$ and total organic carbon are generally used for the geochemical normalization of the metal data as a conservative element (Karim et al., 2015). In our study, Al was used as the reference element for geochemical normalization because its geochemistry is similar to many heavy metals and its natural content tends to be uniform (Ravisankar et al., 2015). $\mathrm{EF}$ is defined as $\mathrm{EF}=(\mathrm{M} / \mathrm{Al})_{\text {sample }} /(\mathrm{M} / \mathrm{Al})_{\text {background }}$ (Bai et al, 2014), where $\mathrm{M}_{\text {sample }}$ and $\mathrm{M}_{\text {background }}$ are the determined contents of targeted elements (e.g., As, $\mathrm{Cd}, \mathrm{Cr}, \mathrm{Cu}, \mathrm{Ni}$, $\mathrm{Pb}$ and $\mathrm{Zn})$ in soil samples and their background values, respectively; $\mathrm{Al}_{\text {sample }}$ and $\mathrm{Al}_{\text {background }}$ are the measured $\mathrm{Al}$ content in soil samples and the Al background value, respectively. Pollution levels were classified into five categories based on $\mathrm{EF}$ values: (1) $\mathrm{EF}<2$, deficiency to minimal enrichment; (2) $\mathrm{EF}=2-5$, moderate enrichment; (3) $\mathrm{EF}=5-20$, significant enrichment; (4) $\mathrm{EF}=$ 20-40, very high enrichment; and (5) $\mathrm{EF}>40$, extremely high enrichment (Han et al., 2006). EF values less than 0.5 reflect the mobilization and loss of the measured element relative to $\mathrm{Al}$ (Zhang, 1995), and those values ranging from 0.5 to 1.5 indicate that the metals are entirely from crustal 
materials or natural weathering processes, whereas EF values higher than 1.5 imply probable anthropogenic pollution sources(Zhang and Liu, 2002).

\subsection{Sediment quality guidelines (SQGs)}

Sediment quality guidelines have been widely applied to the assessment of heavy metal pollution levels in sediment and soil (Bai et al., 2011b; Li et al., 2014). The threshold/probable effect level (TEL/PEL) and the effect range low/median (ERL/ERM) are the most commonly used worldwide to assess sediment toxicity (Zhao et al., 2016; Li et al., 2014). In this study, the SQGs of China (2002), SQGs of US EPA and TEL/PEL guidelines are introduced to assess the pollution levels in four wetlands.

\subsection{Toxic units (TUs)}

Toxic units (TUs) were used to normalize the toxicities of various heavy metals to allow for the comparison of the relative effects (Bai et al., 2011b). TUs are defined as the ratios of the detected contents to the probable effect level (PEL) values (Pedersen et al., 1998). PEL values represent the thresholds of chemical contents above which adverse effects are likely to occur. The PEL values for marine and estuarine ecosystems (Long and MacDonald., 1998) were referenced in this study. And the potential acute toxicity of the heavy metals in a sample can be estimated as the sum of the toxic units ( $\Sigma T \mathrm{TU})$.

\subsection{A new toxic risk index (TRI)}

The toxic units (TUs) might underestimate the ecotoxicity due to no considering the TEL effects. Therefore, we developed a new toxic risk index (TRI) based on the TEL and PEL effects (Long and MacDonald, 1998) for the toxic risk assessment. For a certain heavy metal in one soil sample, the TRI can be calculated by Eq. (1): 
$\operatorname{TRI}_{i}=\sqrt{\left(\left(C_{i} / T E L\right)^{2}+\left(C_{i} / P E L\right)^{2}\right) / 2}$

The integrated toxic risk index for several heavy metals in one soil sample could be calculated by Eq. (2):

$T R I=\sum_{i=1}^{n} T R I_{i}$

where TRI $I_{i}$ is the toxic risk index of a certain heavy metal; $C_{i}$ is the measured content of heavy metal; $\mathrm{n}$ is the number of heavy metals; and TRI is the integrated toxic risk index of one sample.

\subsection{Statistical analysis}

Spearman correlation analysis was performed to reveal the relationships between the measured soil properties and heavy metals. One-way analysis of variance (ANOVA) was used to test the significant differences in soil properties and heavy metals among four wetlands. Difference was considered to be significant if $p<0.05$. Statistical analysis was carried out with SPSS17.0 for Windows software package.

\section{Results and discussion}

\subsection{Soil characterization and heavy metal contents in four wetlands}

Soil physicochemical properties such as $\mathrm{pH}$, SOM, TS and TP can impact the accumulation of heavy metals in wetland soils (Bai et al., 2012; Du Laing et al., 2009; Bai et al., 2011b), so it is essential to analyze their levels and distributions in different wetlands. The mean values of soil properties and heavy metals in four wetlands in the YRD are listed in Table 1. The $\mathrm{pH}$ values in the 40-yr-old wetlands were significantly higher than those in the >50-yr-old and 30-yr-old wetlands $(p<0.05)$, and slightly higher than those in the 10-yr-old wetlands $(p>0.05)$, which might be caused by severe seawater intrusion along with the shortage of fresher input (Xie et al., 2014) in the 40-yr-old wetlands. 
Similarly, the contents of SOM and AP in the 40-yr-old wetlands were slightly or significantly lower than those in other wetlands. However, the highest value of SOM, TP and TS were observed in the 10-yr-old wetlands, which might be associated with shallow sea water pollution and sediment input from the flow-sediment regulation (Bai et al., 2012). In the >50-yr-old wetlands, the AP contents were significantly higher than those in the 30-yr-old and 40 -yr-old wetlands $(p<0.05)$, which could be explained by heavy applications of fertilizers in the reclaimed wetlands. Low TS contents were found in the $>50$-yr-old wetlands, which might be associated with human reclamation activities in this region because wetland reclamation would cause the sulfur loss in soil (Bai et al., 2015).

No significant differences in As contents were observed among four wetlands $(p>0.05$; Table 1), but a slight increase in As along the forming ages exhibited a potential input risk of As in the delta except for higher accumulation in the 10-yr-old wetlands. Comparatively, the Cd contents in the 10-yr-old wetlands was slightly lower compared with the 40 -yr-old wetlands ( $p>0.05)$ and significantly lower than those in the 30-yr-old and $>50$-yr-old wetlands $(p<0.05)$. Similarly, the young wetland soils (i.e., the 10-yr-old and 30-yr-old wetland soils) contained significantly lower Cr contents than the older wetland soils (i.e., the 40-yr-old and >50-yr-old wetlands soils; $p<0.05$ ). Generally, an obvious decrease in $\mathrm{Pb}, \mathrm{Cu}$ and $\mathrm{Zn}$ contents was observed along the wetland-forming chronosequence (Table 1). Similar to $\mathrm{Pb}, \mathrm{Cu}$ and $\mathrm{Zn}, \mathrm{Ni}$ also showed a decreasing trend with increasing ages with the exception of the $>50$-yr-old wetlands. Xie et al.(2014) also presented that the contents of $\mathrm{As}, \mathrm{Ni}, \mathrm{Pb}, \mathrm{Cu}$ and $\mathrm{Zn}$ in the newly-formed wetlands are relatively higher than those in the old wetlands, but the elevated $\mathrm{Cd}$ levels were not observed.

Compared with another three wetlands, the higher $\mathrm{pH}$ values and lower SOM contents in the 
40-yr-old wetlands might be the main cause for lower contents of $\mathrm{Ni}, \mathrm{Pb}, \mathrm{Cu}$ and $\mathrm{Zn}$, because of the lower mobility of heavy metals in these slightly alkaline soils (Kumpiene et al., 2008; Rennert et al., 2010). Soil organic matter (SOM) can act as a major sink for heavy metals due to its strong complexing capacity for metallic contaminants (Bai et al., 2011b; Du Laing et al., 2009). But As, $\mathrm{Cd}$ and Ni were not significantly correlated with SOM (Table 2), which might be ascribed to lower SOM levels in the study area. This is in agreement with the results by Bai et al (2012), who presented that SOM was not considered to represent the main carrier of heavy metals in the YRD.

The intersection of saltwater and freshwater could change the concentration of heavy metals in waters (Tang et al., 2010) by affecting the adsorption and desorption of these heavy metals by wetland soils when the soils were flooded (Bai et al., 2010). TP was significantly related to $\mathrm{Cu}, \mathrm{Pb}$, and $\mathrm{Zn}$ at the level of $p<0.01$ because the phosphorate can reduce the mobility of $\mathrm{Cu}, \mathrm{Pb}$, and $\mathrm{Zn}$ by ionic exchange and precipitation (Kumpiene et al., 2008). Similarly, the strong correlation at the level of $p<0.05$ between TS and $\mathrm{Cu}$ and $\mathrm{Zn}$ might be associated with the formation of insoluble sulfides (e.g., $\mathrm{CuS}$ and $\mathrm{ZnS}$ ) under anoxic conditions due to water flooding (Du Laing et al., 2008).

Additionally, some researchers have demonstrated that the assimilation of heavy metals by wetland plants could obviously lower the contents of $\mathrm{Zn}$ and $\mathrm{Cu}$ and slightly reduce the contents of other toxic heavy metals(e.g., Cr and Cd) in top soils (Brezinová and Vymazal, 2015; Bai et al., 2015; Hu et al., 2013; Bonanno and Lo Giudice, 2010). The decreased amount of heavy metals in soil was considerably associated with the plant biomass and vegetation species (Brezinová and Vymazal, 2015), because plant cycling could accumulate more heavy metals into surface soils (Jobbágy and Jackson, 2001), which might be a contributing factor to the relative high contents of 
$\mathrm{As}, \mathrm{Ni}, \mathrm{Pb}, \mathrm{Cu}$ and $\mathrm{Zn}$ in the 10-yr-old wetland soils with relatively higher SOM (Table 1).

\subsection{Assessment of heavy metals pollution using enrichment factor (EF)}

The enrichment factors (EFs) of relative metals in soil samples could be obtained by comparison with regional background values of the loess materials of the Yellow River (Bai et al., 2015), which were used to evaluate the enrichment levels and the possible anthropogenic inputs of the observed heavy metals (Selvaraj et al., 2004).

Box plots of EFs of heavy metals in surface soils of four wetlands are shown in Figure 2. The $\mathrm{EF}$ values of $\mathrm{As}, \mathrm{Cd}, \mathrm{Cr}, \mathrm{Cu}, \mathrm{Ni}, \mathrm{Pb}$ and $\mathrm{Zn}$ in the study area ranged from 1.10 to 10.95 , 4.45-18.95, 0.71-2.77, 0.76-1.67, 0.73-2.28, 0.55-2.09 and 0.80-2.09, respectively. Generally, $\mathrm{Cu}$, $\mathrm{Cr}, \mathrm{Ni}, \mathrm{Pb}$ and $\mathrm{Zn}$ were minimally or moderately enriched due to the lower $\mathrm{EF}$ values $(\mathrm{EF}<5)$. However, As and Cd reached significant enrichment levels $(5<\mathrm{EF}<20)$, and approximately $31.43 \%$ and $97.14 \%$ of soil samples were heavily polluted by As and Cd. It's worth noting that the EF values for $\mathrm{Cd}$ in all soil samples were greater than 1.5 , which means the Cd pollution in the YRD might be seriously affected by anthropogenic inputs (Zhang and Liu, 2002). Generally, an increasing trends of the $\mathrm{EF}$ values for As and $\mathrm{Ni}$ could be observed along the wetland-forming chronosequence, which implies the accumulation of $\mathrm{As}$ and $\mathrm{Ni}$ as time goes on, and human activities (e.g., petroleum industry and flow-sediment regulation) might cause serious accumulation of As in the whole study area due to higher EF values (Figure 2). The higher EF values for $\mathrm{Cd}$ and $\mathrm{Cr}$ presented in the 40-yr-old wetlands compared with the 30-yr-old and 10-yr-old wetlands indicated more anthropogenic sources for $\mathrm{Cd}$ and $\mathrm{Cr}$ in the older wetlands (i.e., the >50-yr-old and 40-yr-old wetlands). Adversely, the young wetland soils had relatively higher enrichment levels for $\mathrm{Pb}, \mathrm{Cu}$ and $\mathrm{Zn}$ than the older wetland soils (Figure 2) due to higher heavy 
metals from freshwater and sediment inputs affected by the flow-sediment regulation (Bai et al., 2012), but their enrichment levels were still lower than those of As and Cd. Therefore, much more attention should be paid to the $\mathrm{As}$ and $\mathrm{Cd}$ pollution in the whole study area and $\mathrm{Cu}, \mathrm{Pb}$ and $\mathrm{Zn}$ pollution in the younger wetlands in the YRD.

\subsection{Possible source identification}

Multivariate analysis (e.g., Principle component analysis (PCA) and correlation analysis (CA)) has been proved to be an effective tool for source identification of heavy metals (Han et al., 2006; Mico et al., 2006; Bai et al., 2011b; Karim et al., 2014). PCA and CA were applied to assist in the source identification of heavy metals in the whole study area. The results of PCA are shown in Table 3.

Three principle components (PCs) explained $83.09 \%$ of total variance based on eigenvalues (eigenvalue $>1$ ) in the YRD. The PC1, explaining $47.47 \%$ of the total variance, was strongly and positively related to $\mathrm{Al}, \mathrm{Cu}, \mathrm{Ni}, \mathrm{Pb}$ and $\mathrm{Zn}$ (Table 3), and correlation analysis also exhibited significant correlations between them (Table 2). The PC2, explaining $22.60 \%$ of the total variance, showed highly positive factor loadings on $\mathrm{Cd}, \mathrm{Cr}$ and $\mathrm{Ni}$. The PC3, which was strongly related to As, only accounted for $13.02 \%$ of the total variance.

The result of PCA showed that $\mathrm{Al}, \mathrm{Cu}, \mathrm{Ni}, \mathrm{Pb}$ and $\mathrm{Zn}$ might derive from the common sources, $\mathrm{Cd}, \mathrm{Cr}$ and $\mathrm{Ni}$ might share another similar sources, whereas As might originate from the third source in the YRD (Bai et al., 2015). The significant correlations among these metals (e.g., $\mathrm{Al}, \mathrm{Cu}$, $\mathrm{Ni}, \mathrm{Pb}$ and $\mathrm{Zn}$; $\mathrm{Cd}$ and $\mathrm{Cr}$; $\mathrm{Cr}$ and $\mathrm{Ni}$; Table 2) further implied that they had common sources, which is consistent with the result of the PCA.

Some studies have proved that the association of these metals with the PCs could be 
indicated by the anthropogenic influence or geogenic and pedogenic characteristics (Han et al., 2006; Martin et al., 2006). Therefore, PC1 could be defined as a lithogenic component seemed to be controlled by parent rocks, whereas PC2 and PC 3 could be identified as an anthropogenic component due to the high $\mathrm{EF}$ values of $\mathrm{Cd}, \mathrm{Cr}$ and As (Figure 2). The applications of agrochemicals and fertilizers in the drainage plain of the YRD in addition to the oilfield pollution might be important sources of $\mathrm{As}, \mathrm{Cd}, \mathrm{Pb}$ and $\mathrm{Zn}$ (Lu et al., 2014). Tang et al. (2010) observed that higher As and Cd concentrations in the seawater of the Yellow River Estuary were primarily affected by inputs from the Yellow River. It implies seawater flooding and river inputs could affect the contents of heavy metals (e.g., As and Cd ) in wetland soils of the YRD. Zhang et al. (2012) also stated that wetlands directly connected with rivers have much higher metal contents than those indirectly connected with rivers. Additionally, Bai et al. (2012) presented that the contents of As and Cd were significantly elevated after flow-sediment regulation.

Generally, the heavy metals mainly originated from natural alluviation and sedimentation ( $\mathrm{Li}$ et al., 2014) and were distinctly affected by the anthropogenic processes (e.g., agrochemicals, fertilizers, and oil production). Moreover, the sources and composition/structure of heavy metals in surface soils would change with the changing environmental conditions such as water discharge, sediment loads, deposition rates and grain size (Bai et al., 2012; Mico et al., 2006), and the interaction among those factors makes the identification of heavy metals more complex. Meanwhile, atmospheric deposition might be also a subordinate source of metals in the YRD (Lu et al., 2014; Luo et al., 2010).

\subsection{Assessment of heavy metals pollution using sediment quality guidelines (SQGs)}

According to the background values of heavy metals in the YRD (Table 4), $\mathrm{Cr}$ and $\mathrm{Ni}$ 
contents in more than $80 \%$ of soil samples exceeded their background values, however, $\mathrm{Cu}, \mathrm{Pb}$ and $\mathrm{Zn}$ contents in $60 \%-68.57 \%$ of the soil samples were below their background values. In addition, $\mathrm{Cu}, \mathrm{Pb}$ and $\mathrm{Zn}$ levels in all soil samples in the 40-yr-old wetlands were below the background values. According to the SQGs of China (Table 4), the mean contents of As, Cd and $\mathrm{Ni}$ in four wetlands fell within the scope of Class I and Class II criteria (Tables1 and 4). And lower mean levels of $\mathrm{Cr}$ were observed in the younger wetlands (i.e., the 10-yr-old and 30-yr-old wetlands), which didn't exceed Class I criteria ( $80 \mathrm{mg} / \mathrm{kg}$ ). Meanwhile, the mean values of $\mathrm{Pb}, \mathrm{Cu}$ and $\mathrm{Zn}$ in four wetlands were below the Class I criteria, which indicates low pollution levels of $\mathrm{Pb}$, $\mathrm{Cu}$ and $\mathrm{Zn}$ in the whole study area. Generally, wetland soils in the YRD were moderately polluted by $\mathrm{As}, \mathrm{Cd}$ and $\mathrm{Ni}$, and more attention should be paid to the younger wetlands, especially the 10-yr-old wetlands (Table 1). According to the SQGs of US EPA (Table 4), all these wetland soils in four wetlands were heavily polluted by As and moderately polluted by $\mathrm{Ni}$. As for $\mathrm{Cr}$, the younger wetlands (i.e., the 10-yr-old and 30-yr-old wetlands) were moderately polluted and the older wetlands (i.e., the 40-yr-old and >50-yr-old wetlands) were heavily polluted. Comparatively, all soil samples were not polluted by $\mathrm{Pb}$ in this region. With the exception of the 10-yr-old wetlands with moderate pollution of $\mathrm{Cu}$ and $\mathrm{Zn}$, no pollution of $\mathrm{Cu}$ and $\mathrm{Zn}$ was observed in another three wetlands.

The threshold effect levels (TELs) and probable effect levels (PELs) were developed to evaluate the ecotoxicology of heavy metals in wetland soils for marine ecosystems (Long and MacDonald, 1998). The TELs represent the low threshold contents below which adverse effects upon sediment dwelling fauna would be infrequently expected, and the PELs represent the high threshold concentrations above which the toxic effects on ecosystem are likely to occur (Bai et al., 
2015). All soil samples did not exceed the PEL values for $\mathrm{Cd}, \mathrm{Cr}, \mathrm{Cu}, \mathrm{Pb}$ and $\mathrm{Zn}$ in four wetlands, but $31.43 \%$ (for As) and $11.43 \%$ (for $\mathrm{Ni}$ ) of soil samples had contents in excess of the PELs. Almost all soil samples showed As and Ni levels exceeding TELs values in four wetlands. Generally, As, Cd and Ni were identified as heavy metals of primary concerns in four wetlands and $\mathrm{Cr}$ was of moderate concern in older wetlands (i.e., the >50-yr-old and 40-yr-old wetlands), and $\mathrm{Pb}, \mathrm{Cu}$ and $\mathrm{Zn}$ should be paid more attention in younger wetland (i.e, the 10-yr-old and 30-yr-old wetlands).

\subsection{Assessment of heavy metals pollution using toxic units (TUs) and a new toxic risk index}

(TRI)

Toxic units (TUs) are defined as the ratios of the detected contents to the (PEL) values which are used to normalize the toxicities caused by various heavy metals and thus allowed the comparison of their relative effects (Pedersen et al., 1998) and the potential acute toxicity of the heavy metals in a soil sample can be estimated as the sum of the toxic units ( $\sum \mathrm{TUs}$ ). Figure 3 illustrates the $\sum$ TUs values of four wetlands based on the contents of $\mathrm{As}, \mathrm{Cd}, \mathrm{Cr}, \mathrm{Cu}, \mathrm{Ni}, \mathrm{Pb}$ and $\mathrm{Zn}$. The $\sum$ TUs values for all soil samples ranged from 1.66 to 4.31 . Among four wetlands, the mean values of $\sum$ TUs were in the following order: the 40 -yr-old wetlands $(2.56 \pm 0.47)<$ the 30 -yr-old wetlands $(2.66 \pm 0.33)<$ the $>50$-yr-old wetlands $(3.09 \pm 0.47)<$ the 10 -yr-old wetlands (3.41 \pm 0.73 ), which indicates that the newly-formed wetlands along the river and the older wetland affected by farmland and oil production showed higher potential toxic risks. Therefore, some proactive measures are required to control heavy metal pollution caused by human activities in these wetlands.

Generally, the $\sum$ TUs for $20 \%$ of the 10 -yr-old wetland soil samples were higher than 4 , 
which means moderate toxicity to ecosystem (Pedersen et al., 1998) in the study area. The average heavy metals toxic units in four wetlands decreased in the following order $\mathrm{As}>\mathrm{Ni}>\mathrm{Cr}>\mathrm{Zn}>\mathrm{Cu}$ $>\mathrm{Pb}>\mathrm{Cd}$, and the contributing ratios of seven heavy metals in all samples to $\sum$ TUs were $28.86 \pm 9.51 \%$ for As, $26.74 \pm 4.42 \%$ for $\mathrm{Ni}, 17.54 \pm 4.87 \%$ for $\mathrm{Cr}, 8.69 \pm 2.67 \%$ for $\mathrm{Zn}, 6.12 \pm 1.46 \%$ for $\mathrm{Cu}, 6.03 \pm 2.06 \%$ for $\mathrm{Pb}$ and $6.02 \pm 1.70 \%$ for $\mathrm{Cd}$, respectively. This implies that $\mathrm{As}, \mathrm{Ni}$ and $\mathrm{Cr}$ exhibited higher potential toxicity to the fragile coastal wetlands in the YRD. Cd made a lower toxicity contribution to the $\sum \mathrm{TUs}$ despite its higher pollution level on the basis of the EF values. The assessment of TUs approach would certainly underestimate its toxicity because of the much higher PEL value of Cd. Therefore, a complementary approach including standard soil criteria and diffident assessment methods should be considered to provide a more accurate and comprehensive assessment of the risk from metals to the environment ( $\mathrm{Lu}$ et al., 2014).

We calculated the toxic risks of all soil samples in four wetlands using the new toxic risk index (TRI) (Figure 4). The pollution classification based on TRI values is shown in Table 5. TRI values ranged from 4.36 to 12.99 , with the highest value in the 10 -yr-old wetlands and the lowest value in 40-yr-old wetlands, which was consistent with the $\sum$ TUs values. Compared with the TUs values, more soil samples with moderate toxicity can be identified based on the TRI (Figures 3 and 4). For example, the TRI values for $40 \%$ of the 10 -yr-old wetland soil samples and $33.33 \%$ of the $>50$-yr-old wetland soil samples were beyond 10, which indicates moderate toxic risk for those samples.

The average contributing ratios of seven heavy metals to TRI values were $39.70 \pm 11.18 \%$ for As, $18.47 \pm 3.97 \%$ for $\mathrm{Ni}, 13.61 \pm 4.30 \%$ for $\mathrm{Cr}, 9.03 \pm 2.80 \%$ for $\mathrm{Cd}, 8.61 \pm 2.20 \%$ for $\mathrm{Cu}, 5.57 \pm$ $1.95 \%$ for $\mathrm{Pb}$ and $5.01 \pm 1.60 \%$ for $\mathrm{Zn}$. The $\mathrm{As}, \mathrm{Ni}, \mathrm{Cr}$ and $\mathrm{Cd}$ should be paid more attention due to 
their high contributing ratios to TRI values. The strong correlation between $\sum$ TUs and TRI values (Figure 5) indicated that the TRI is an acceptable tool for the accurate assessment of ecological toxicity. Moreover, the contributing ratio of $\mathrm{Cd}(9.03 \pm 2.80 \%)$ was elevated based on the TRI method compared with the ratio of $\mathrm{Cd}(6.02 \pm 1.70 \%)$ in $\sum \mathrm{TUs}$, reflecting higher Cd pollution risk.

\section{Conclusions}

This study investigated the levels, sources and toxic risks of heavy metals (i.e., As, $\mathrm{Cd}, \mathrm{Cr}$, $\mathrm{Cu}, \mathrm{Ni}, \mathrm{Pb}$ and $\mathrm{Zn}$ ) in different wetland soils along a wetland-forming chronosequence in the Yellow River Delta. The EF values for As and Cd were relatively higher than other heavy metals in four wetlands, whereas an increasing tendency of $\mathrm{EF}$ values for $\mathrm{Cu}, \mathrm{Pb}$ and $\mathrm{Zn}$ could be observed from the $>50$-yr-old wetlands to the 10 -yr-old wetlands, which could be ascribed to the freshwater and sediment inputs from upstream of the $\mathrm{YRD} . \mathrm{Al}, \mathrm{Cu}, \mathrm{Ni}, \mathrm{Pb}$ and $\mathrm{Zn}$ might originate from parent rocks, $\mathrm{Cd}, \mathrm{Cr}$ and $\mathrm{Ni}$, and As might share other sources such as agrochemicals, fertilizers and oil production.

Although the pollution levels of $\mathrm{As}, \mathrm{Cd}$ and $\mathrm{Ni}$ were slight in four wetlands according to the SQGs of China, however, heavy As pollution and moderate Ni pollution were identified according to the SQGs of US EPA. Generally, the measured heavy metals exhibited lower ecotoxicity in this study area, with higher contribution ratios of $\mathrm{As}, \mathrm{Ni}$ and $\mathrm{Cr}$ to the sum of TUs. A new toxic risk index (TRI) was developed for assessing the potential toxic risk of heavy metals. Compared with the approach of TUs, the introduced new index (TRI) is more sensitive and effective because it combines the TEL/PEL values and can identify more potential polluted soils and give more accurate toxic sequencing for each heavy metal. A long-term dynamic monitoring of heavy metals such as $\mathrm{As}, \mathrm{Ni}, \mathrm{Cr}$ and $\mathrm{Cd}$ is needed to avoid potential ecological risks and protect wetland 
ecosystem health. Moreover, the influencing mechanisms of the changing flow-sediment conditions on the movement and transformation of heavy metals in these coastal wetlands need to be studied in the future.

\section{Acknowledgements}

This study was financially supported by the National Basic Research Program of China (no. 2013CB430406), the National Science Foundation for Innovative Research (no. 51421065), the National Natural Science Foundation (no. 51379012) and the Young Top-Notch Talent Support Program of China. The authors acknowledge all colleagues for their contributions to the fieldwork.

\section{References}

Bai, J.H., Huang, L.B., Yan, D.H., Wang, Q.G., Gao, H.F., Xiao, R., Huang, C., 2011a. Contamination characteristics of heavy metals in wetland soils along a tidal ditch of the Yellow River Estuary, China. Stoch. Env. Res. Risk A. 25, 671-676.

Bai, J.H., Xiao, R., Cui, B.S., Zhang, K.J., Wang, Q.G., Liu, X.H., Gao, H.F., Huang, L.B., 2011b. Assessment of heavy metal pollution in wetland soils from the young and old reclaimed regions in the Pearl River Estuary, South China. Environ. Pollut. 159, 817-824.

Bai, J.H., Xiao, R., Zhang, K.J., Gao, H.F., 2012. Arsenic and heavy metal pollution in wetland soils from tidal freshwater and salt marshes before and after the flow-sediment regulation regime in the Yellow River Delta, China. J. Hydrol. 450-451, 244-253.

Bai, J.H., Xiao, R., Zhao, Q.Q., Lu, Q.Q., Wang, J.J., Reddy, K.R., 2014. Seasonal dynamics of trace elements in tidal salt marsh soils as affected by the flow-sediment regulation regime. 
PLoS ONE 9(9), e107738. doi:10.1371/journal.pone.0107738.

Bai, J.H., Zhao, Q.Q., Lu, Q.Q., Wang, J.J., Reddy, K.R., 2015. Effects of freshwater input on trace element pollution in salt marsh soils of a typical coastal estuary, China. J. Hydrol. 520, $186-192$.

Bonanno, G., Lo Giudice, R., 2010. Heavy metal bioaccumulation by the organs of Phragmites australis (common reed) and their potential use as contamination indicators. Ecol. Indic. 10 (3), 639-645.

Brezinová, T., Vymazal, J., 2015. Evaluation of heavy metals seasonal accumulation in Phalaris arundinacea in a constructed treatment wetland. Ecol. Eng. 79, 94-99.

Cenci, R.M., Martin, J.M., 2004. Concentration and fate of trace metals in Mekong River Delta. Sci. Total Environ. 332, 167-182.

China National Environmental Monitoring Center (CNEMC), 1990. Chinese elemental background values for soils. Chinese Environmental Science Press, Beijing.

Deforest, D.K., Brix, K.V., Adams, W.J., 2007. Assessing metal bioaccumulation in aquatic environments: the inverse relationship between bioaccumulation factors, trophic transfer factors and exposure concentration. Aquat. Toxicol. 84 (2), 236-246.

Du Laing, G., DeVos, R., Vandecasteele, B., Lesage, E., Tack, F.M.G., Verloo, M.G., 2008. Effect of salinity on heavy metal mobility and availability in intertidal sediments of the Scheldt estuary. Estuar. Coast. Shelf S. 77(4), 589-602.

Du Laing, G., Rinklebe, J., Vandecasteele, B., Meers, E., Tack, F.M.G., 2009. Trace metal behaviour in estuarine and riverine floodplain soils and sediments: a review. Sci. Total. Environ. 407, 3972-3985. 
Environmental Protection Department of Hong Kong (EPDHK), 2005. Marine Water Quality in HongKong in 2004 - Sediment Quality. Environmental Protection Department of Hong Kong SAR, Hong Kong.

Gorenc, S., Kostaschuk, R., Chen, Z., 2004. Spatial variations in heavy metals on tidal flats in the Yangtze Estuary, China. Environ. Geol. 45, 1101-1108.

Grabowski, L.A., Houpis, J.L.J., Woods, W.I., Johnson, K.A., 2001. Seasonal bioavailability of sediment-associated heavy metals along the Mississippi river floodplain. Chemosphere 45, $643-651$

Guo, G.H., Wu, F.C., Xie, F.Z., Zhang, R.Q., 2012. Spatial distribution and pollution assessment of heavy metals in urban soils from southwest China. J. Environ. Sci. 24 (3), 410-418.

Han, Y.M., Du, P.X., Cao, J.J., Posmentier, E.S., 2006. Multivariate analysis of heavy metal contamination in urban dusts of Xi'an, Central China. Sci. Total Environ. 355, 176-186.

Huang, L.B., Bai, J.H., Chen, B., Zhang, K.J., Huang, C., Liu, P.P., 2012. Two-decade wetland cultivation and its effects on soil properties in salt marshes in the Yellow River Delta, China. Ecol. Inform. 10, 49-55.

Hu, G., Bi, S.P., Xu, G., Zhang, Y., Mei, X., Li, A.C., 2015. Distribution and assessment of heavy metals off the Changjiang River mouth and adjacent area during the past century and the relationship of the heavy metals with anthropogenic activity. Mar. Pollut. Bull. 96, 434-440.

Hu, X.F., Du, Y., Feng, J.W., Fang, S.Q., Gao, X.J., Xu, S.Y., 2013. Spatial and seasonal variations of heavy metals in wetland soils of the tidal flats in the Yangtze Estuary, China:Environmental Implications. Pedosphere 23(4), 511-522.

Jobbágy, E.G., Jackson, R.B., 2001. The distribution of soil nutrients with depth: global patterns 
and the imprint of plants. Biogeochemistry 53, 51-77.

Karim, Z., Qureshi, B.A., Mumtaz, M., Qureshi, S., 2014. Heavy metal content in urban soils as an indicator of anthropogenic and natural influences on landscape of Karachi-A multivariate spatio-temporal analysis. Ecol. Indic. 42: 20-31.Karim, Z., Qureshi, B.A., Mumtaz, M., 2015. Geochemical baseline determination and pollution assessment of heavy metals in urban soils of Karachi, Pakistan. Ecol. Indic. 48, 358-364.

Kennish, M.J., 1992. Ecology of Estuaries: Anthropogenic Effects. CRC Press, Inc., Boca Raton, FL, pp 494.

Kumpiene, J., Lagerkvist, A., Maurice, C., 2008. Stabilization of $\mathrm{As}, \mathrm{Cr}, \mathrm{Cu}, \mathrm{Pb}$ and $\mathrm{Zn}$ in soil using amendments ea review. Waste Manage. 28, 215-225.

Li, F.L., Chen,X., 2003. Shoreline changes of the Yellow River Delta and its sub-delta area forecase. In International conference on estuaries and coasts, Hangzhou, China. 246-254.

Li, L., Wang, X.J., Zhu, A.M., Yang, G., Liu, J.H., 2014. Assessing metal toxicity in sediments of Yellow River wetland and its surrounding coastal areas, China. Estuar. Coast. Shelf S. 151, 302-309.

Li, Q.S., Wu, Z.F., Chu, B., Zhang, N., Cai, S.S., Fang, J.H., 2007. Heavy metals in coastal wetland sediments of the Pearl River Estuary, China. Environ. Pollut. 149, 158-164.

Liu, X.Z., Qi, S.Z., 2011. Wetlands environmental degradation in the Yellow River Delta, Shandong Province of China. Procedia Environ. Sci. 11, 701-705.

Long, E.R., MacDonald, D.D., 1998. Recommended uses of empirically derived, sediment quality guidelines for marine and estuarine ecosystems. Hum. Ecol. Risk Assess. 4(5), 1019-1039.Long, E.R., MacDonald, D.D., Severn, C.G., Hong, C.B., 2000. Classifying 
probabilities of acute toxicity in marine sediments with empirically derived sediment quality guidelines. Environ. Toxicol. Chem. 19(10), 2598-2601.

Lu, Q.Q., Bai, J.H., Gao, Z.Q., Zhao, Q.Q., Wang, J.J., 2014. Spatial and seasonal distribution and risk assessments for metals in a Tamarix chinensis wetland, China. Wetlands. DOI 10.1007/s13157-014-0598-y

Luo, W., Lu, Y.L., Wang, T.Y., Hu, W.Y., Jiao, W.T., Naile, J.E., Khim, J.S., Giesy, J.P., 2010. Ecological risk assessment of arsenic and metals in sediments of coastal areas of northern Bohai and Yellow Seas, China. Ambio 39(5-6), 367-375.

Maanan, M., Saddik, M., Maanan, M., Chaini, M., Assobhei, O., Zourarah, B., 2015. Environmental and ecological risk assessment of heavy metals in sediments of Nador lagoon, Morocco. Ecol. Indic. 48: 616-626.

Martin, J.A.R.G., Arias, M.L.P., Corb, J.M.G., 2006. Heavy metal contents in agricultural topsoils in the Ebro basin (Spain). Application of the multivariate geoestatistical methods to study spatial variations. Environ. Pollut. 144, 1001-1012.

Mico, C., Recatala, L., Peris, M., Sanchez, J., 2006. Assessing heavy metal sources in agricultural soils of an European Mediterranean area by multivariate analysis. Chemosphere 65, 863-872.

Nie, M., Xian, N.X., Fu, X.H., Chen, X.F., Li, B., 2010. The interactive effects of petroleum-hydrocarbon spillage and plant rhizosphere on concentrations and distribution of heavy metals in sediments in the Yellow River Delta, China. J. Hazard. Mater. 174, 156-161.

Pedersen, F., Bjùrnestad, E., Andersen, H.V., Kjøholt, J., Poll, C., 1998. Characterization of sediments from Copenhagen Harbour by use of biotests. Water Sci. Technol. 37 (6-7), 233-240. 
Pejman, A., Bidhendi, G.N., Ardestani, M., Saeedi, M., Baghvand, A., 2015. A new index for assessing heavy metals contamination in sediments: A case study. Ecol. Indic. 58, 365-373.

Ravisankar, R., Sivakumar, S., Chandrasekaran, A., Kanagasabapathy, K.V., Prasad, M.V.R., Satapathy, K.K., 2015. Statistical assessment of heavy metal pollution in sediments of east coast of Tamilnadu using Energy Dispersive X-ray Fluorescence Spectroscopy (EDXRF). Appl. Radiat. Isotopes 102, 42-47.

Rennert, T., Meibner, S., Rinklebe, J., Totsche, K.U., 2010. Dissolved inorganic contaminants in a floodplain soil: comparison of in situ soil solutions and laboratory methods. Water Air Soil Poll. 209, 489-500.

Selvaraj, K., Ram Mohan ,V., Szefer, P., 2004. Evaluation of metal contamination in coastal sediments of the Bay of Bengal, India: geochemical and statistical approaches. Mar. Pollut. Bull. 49, 174-185.

Sun, Z.G., Mou, X.J., Tong, C., Wang, C.Y., Xie, Z.L., Song, H.L., Sun, W.G., Lv, Y.C., 2015. Spatial variations and bioaccumulation of heavy metals in intertidal zone of the Yellow River estuary, China. Catena 126,43-52.

Tang, A., Liu, R., Ling, M., Xu, L.M., Wang, J.Y., 2010. Distribution characteristics and controlling factors of soluble heavy metals in the yellow river estuary and adjacent sea. Procedia Environ. Sci. 2, 1193-1198.

Vital, H., Stattegger, K., 2000. Major and trace elements of stream sediments from the lowermost Amazon River. Chem. Geol. 168, 151-168.

Walkley, A.J., Black, I.A., 1934. An examination of the Degtjareff method for determining soil organic matter and a proposed modification of the chromic acid titration method. Soil Sci. 
$37(1), 29-38$.

Wang, L., Coles, N.A., Wu, C.F., Wu, J.P., 2014. Spatial variability of heavy metals in the coastal soils under long-term reclamation. Estuar. Coast. Shelf S. 151, 310-317.

Williams, T.P., Bubb, J.M., Lester, J.N., 1994. Metal accumulation within salt marsh environments: a review. Mar. Pollut. Bull. 28, 277-290.

Xiao, R., Bai, J.H., Gao, H.F., Huang, L.B., Huang, C., Liu, P.P., 2012. Heavy metals (Cr and Ni) distribution and fractionation in cropland soils from reclaimed tidal wetlands in Pearl River estuary, South China. Procedia Environ.l Sci. 13, 1684-1687.

Xie, Z.L., Zhao, G.S., Sun, Z.G., Liu, J.Y., 2014. Comparison of arsenic and heavy metals contamination between existing wetlands and wetlands created by river diversion in the Yellow River estuary, China. Environ. Earth. Sci. 72, 1667-1681.

Xu, X.G., Guo, H.H., Chen, X.L., Lin, H.P., Du, Q.L., 2002. A multi-scale study on land use and land cover quality change: the case of the Yellow River Delta in China. Geoj. 56(3), 177-183.

Yang, Z.S., Ji, Y.J., Bi, N.S., Lei, K., Wng, H.J., 2011. Sediment transport off the Huanghe (Yellow River) delta and in the adjacent Bohai Sea in winter and seasonal comparison. Estuar. Coast. Shelf S. 93, 173-181.

Ye, S., Laws, E.A., Yuknis, N., Ding, X., Yuan, H., Zhao, G., Wang, J., Yu, X., Pei, S., De Laune, R.D., 2015. Carbon Sequestration and Soil Accretion in Coastal Wetland Communities of the Yellow River Delta and Liaohe Delta, China. Estuar. Coast. 38, 1885-1897.

Yu, H., Ni, S.J., He, Z.W., Zhang, C.J., Nan, X., Kong, B., Weng, Z.Y., 2014. Analysis of the spatial relationship between heavy metals in soil and human activities based on landscape geochemical interpretation. J. Geochem. Explor. 146,136-148. 
Zhang, H.G., Cui, B.S., Zhang, K.J., 2012. Surficial and vertical distribution of heavy metals in different estuary wetlands in the Pearl River,South China. Clean Soil Air Water 40, 1174-1184.

Zhang, H.G., Cui, B.S., Xiao, R., Zhao, H., 2010. Heavy metals in water, soils and plants in riparian wetlands in the Pearl River Estuary, South China. Procedia Environ. Sci. 2, $1344-1354$.

Zhang, J., 1995. Geochemistry of trace metals from Chinese river/estuary systems: an overview. Estuar. Coast. Shelf S. 41 (6), 631-658.

Zhang, J., Liu, C.L., 2002. Riverine composition and estuarine geochemistry of particulate metals in China - weathering features, anthropogenic impact and chemical fluxes. Estuar. Coast. Shelf S. 54 (6), 1051-1070.

Zhang, M.Y., Cui, L.J., Sheng, L.X., Wang, Y.F., 2009. Distribution and enrichment of heavy metals among sediments, water body and plants in Hengshuihu Wetland of Northern China. Ecol. Eng. 35, 563-569.

Zhao, Q.Q., Bai, J.H., Huang, L.B., Gu, B.H., Lu, Q.Q., Gao, Z.Q., 2016. A review of methodologies and success indicators for coastal wetland restoration. Ecol. Indic. 60: $442-452$.

Zhou,Y.Y., Huang,H.Q., Nanson,G.C., Huang,C., Liu,G.H., 2015. Progradation of the Yellow (Huanghe) River delta in response to the implementation of a basin-scale water regulation program. Geomorphology 243, 65-74.

Zong, X.Y., Liu, G.H., Qiao, Y.L., Lin, S., 2009. Study on dynamics changes of wetland landscape pattern in Yellow River Delta. J. Geo-information Sci. 11(1), 91-97 (in Chinese). 
Table 1 Soil characterization and heavy metals concentrations in four types of wetlands (Data are shown as the mean \pm SD)

\begin{tabular}{lcccccc}
\hline \multicolumn{1}{c}{ Soil properties } & $\mathrm{pH}$ & $\mathrm{SOM}(\mathrm{g} / \mathrm{kg})$ & $\mathrm{AP}(\mathrm{mg} / \mathrm{kg})$ & $\mathrm{TP}(\mathrm{mg} / \mathrm{kg})$ & $\mathrm{TS}(\mathrm{mg} / \mathrm{kg})$ & $\mathrm{Al}(\mathrm{mg} / \mathrm{kg})$ \\
\hline$>50$-yr-old$(\mathrm{n}=15)$ & $8.18 \pm 0.05^{\mathrm{a}}$ & $4.51 \pm 2.48^{\mathrm{ab}}$ & $7.08 \pm 4.39^{\mathrm{a}}$ & $598.1 \pm 40.1^{\mathrm{ab}}$ & $497.9 \pm 150.8^{\mathrm{a}}$ & $51105.7 \pm 4037.7^{\mathrm{a}}$ \\
40 -yr-old$(\mathrm{n}=7)$ & $8.44 \pm 0.13^{\mathrm{b}}$ & $1.92 \pm 1.34^{\mathrm{a}}$ & $2.28 \pm 0.64^{\mathrm{b}}$ & $556.0 \pm 68.5^{\mathrm{a}}$ & $593.0 \pm 165.5^{\mathrm{ab}}$ & $40145.2 \pm 11363.0^{\mathrm{b}}$ \\
30 -yr-old(n=8) & $8.16 \pm 0.20^{\mathrm{a}}$ & $6.70 \pm 3.94^{\mathrm{bc}}$ & $3.13 \pm 0.65^{\mathrm{b}}$ & $664.9 \pm 102.7^{\mathrm{b}}$ & $514.6 \pm 86.1^{\mathrm{a}}$ & $54714.7 \pm 12279.0^{\mathrm{a}}$ \\
10 -yr-old(n=5) & $8.28 \pm 0.25^{\mathrm{ab}}$ & $7.76 \pm 3.87^{\mathrm{c}}$ & $5.62 \pm 1.61^{\mathrm{a}}$ & $768.1 \pm 73.2^{\mathrm{c}}$ & $718.7 \pm 112.7^{\mathrm{b}}$ & $59756.4 \pm 13290.3^{\mathrm{a}}$ \\
\hline
\end{tabular}

(continued)

\begin{tabular}{|c|c|c|c|c|c|c|c|}
\hline Soil properties & $\mathrm{As}(\mathrm{mg} / \mathrm{kg})$ & $\mathrm{Cd}(\mathrm{mg} / \mathrm{kg})$ & $\mathrm{Cr}(\mathrm{mg} / \mathrm{kg})$ & $\mathrm{Ni}(\mathrm{mg} / \mathrm{kg})$ & $\mathrm{Pb}(\mathrm{mg} / \mathrm{kg})$ & $\mathrm{Cu}(\mathrm{mg} / \mathrm{kg})$ & $\mathrm{Zn}(\mathrm{mg} / \mathrm{kg})$ \\
\hline$>50-$ yr-old $(n=15)$ & $36.78 \pm 16.68^{\mathrm{a}}$ & $0.76 \pm 0.16^{\mathrm{a}}$ & $95.78 \pm 15.52^{\mathrm{a}}$ & $36.62 \pm 4.63^{\mathrm{a}}$ & $18.92 \pm 3.71^{\mathrm{a}}$ & $18.69 \pm 3.44^{\mathrm{a}}$ & $61.88 \pm 13.49^{\mathrm{a}}$ \\
\hline $40-y r-o l d(n=7)$ & $34.56 \pm 20.02^{\mathrm{a}}$ & $0.70 \pm 0.13^{\mathrm{ab}}$ & $84.25 \pm 10.92^{\mathrm{a}}$ & $27.58 \pm 6.47^{\mathrm{b}}$ & $11.68 \pm 5.13^{b}$ & $13.99 \pm 3.46^{\mathrm{b}}$ & $44.18 \pm 10.01^{\mathrm{b}}$ \\
\hline $30-$ yr-old $(n=8)$ & $31.95 \pm 7.35^{\mathrm{a}}$ & $0.77 \pm 0.18^{\mathrm{a}}$ & $64.02 \pm 21.48^{\mathrm{b}}$ & $28.43 \pm 6.61^{b}$ & $19.90 \pm 6.00^{\mathrm{a}}$ & $20.21 \pm 3.46^{\mathrm{a}}$ & $74.36 \pm 13.45^{\mathrm{a}}$ \\
\hline $10-\mathrm{yr}-\mathrm{old}(\mathrm{n}=5)$ & $41.96 \pm 10.74^{\mathrm{a}}$ & $0.55 \pm 0.16^{\mathrm{b}}$ & $59.70 \pm 19.21^{\mathrm{b}}$ & $39.96 \pm 9.09^{\mathrm{a}}$ & $34.42 \pm 4.79^{c}$ & $26.44 \pm 5.47^{\mathrm{c}}$ & $111.09 \pm 17.69^{c}$ \\
\hline
\end{tabular}

${ }^{\text {abc }}$ Values in each column with the same letter are not significantly (LSD) different between different wetland $(p<0.05)$ 
Table 2 Spearman correlation matrix between heavy metals and selected soil properties in the whole study area

\begin{tabular}{|c|c|c|c|c|c|c|c|c|c|c|c|c|c|}
\hline & $\mathrm{pH}$ & SOM & AP & $\mathrm{TP}$ & $\mathrm{TS}$ & $\mathrm{Al}$ & As & $\mathrm{Cd}$ & $\mathrm{Cr}$ & $\mathrm{Cu}$ & $\mathrm{Ni}$ & $\mathrm{Pb}$ & $\mathrm{Zn}$ \\
\hline $\mathrm{pH}$ & 1.000 & & & & & & & & & & & & \\
\hline SOM & -0.232 & 1.000 & & & & & & & & & & & \\
\hline AP & -0.200 & 0.174 & 1.000 & & & & & & & & & & \\
\hline $\mathrm{TP}$ & -0.047 & $0.626^{* *}$ & 0.322 & 1.000 & & & & & & & & & \\
\hline $\mathrm{TS}$ & 0.088 & 0.265 & 0.149 & $0.503^{* *}$ & 1.000 & & & & & & & & \\
\hline $\mathrm{Al}$ & -0.120 & $0.510^{* *}$ & 0.332 & $0.817^{* *}$ & $0.438^{* *}$ & 1.000 & & & & & & & \\
\hline As & 0.244 & 0.107 & -0.009 & 0.209 & -0.010 & 0.135 & 1.000 & & & & & & \\
\hline $\mathrm{Cd}$ & $-0.419^{*}$ & -0.133 & 0.065 & -0.202 & -0.173 & -0.152 & -0.154 & 1.000 & & & & & \\
\hline $\mathrm{Cr}$ & -0.280 & -0.328 & 0.209 & $-0.401^{*}$ & -0.227 & -0.184 & -0.124 & $0.426^{*}$ & 1.000 & & & & \\
\hline $\mathrm{Cu}$ & -0.300 & $0.563^{* *}$ & $0.384^{*}$ & $0.690^{* *}$ & $0.412^{*}$ & $0.787^{* *}$ & 0.000 & 0.135 & -0.166 & 1.000 & & & \\
\hline $\mathrm{Ni}$ & -0.296 & 0.198 & $0.661^{* *}$ & 0.289 & 0.114 & $0.345^{*}$ & 0.094 & 0.256 & $0.389^{*}$ & $0.534^{* *}$ & 1.000 & & \\
\hline $\mathrm{Pb}$ & -0.090 & $0.486^{* *}$ & $0.544^{* *}$ & $0.774^{* *}$ & 0.256 & $0.660^{* *}$ & 0.103 & -0.188 & -0.308 & $0.651^{* *}$ & $0.553^{* *}$ & 1.000 & \\
\hline $\mathrm{Zn}$ & -0.232 & $0.609^{* *}$ & 0.322 & $0.752^{* *}$ & $0.404^{*}$ & $0.703^{* *}$ & 0.036 & -0.040 & $-0.387^{*}$ & $0.827^{* *}$ & $0.411^{*}$ & $0.748^{* *}$ & 1.000 \\
\hline
\end{tabular}

* Significant correlation at the level of $p<0.05$; ** Significant correlation at the level of $p<0.01$. 
Table 3 Results of principle component analysis of heavy metals for the whole study area. Factor loadings exceeding 0.5 are shown in bold.

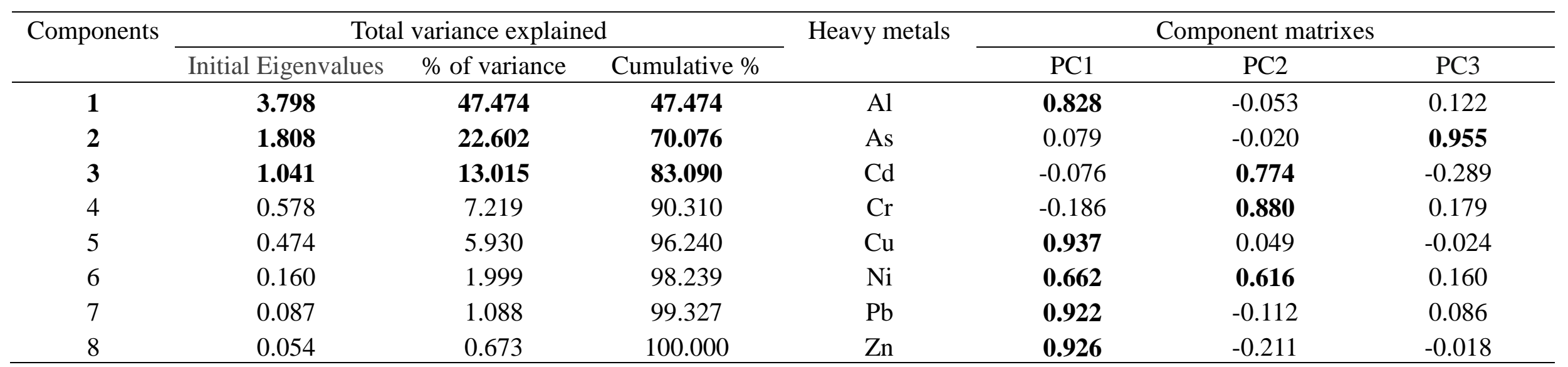


Table 4 The sediment quality guideline of China, sediment quality guidelines (SQGs) for marine ecosystem, the SQGs of US EPA and background values of heavy metals in YRD.

\begin{tabular}{|c|c|c|c|c|c|c|c|c|c|}
\hline & & $\begin{array}{c}\mathrm{Al} \\
(\mathrm{mg} / \mathrm{kg})\end{array}$ & $\begin{array}{c}\text { As } \\
(\mathrm{mg} / \mathrm{kg})\end{array}$ & $\begin{array}{c}\mathrm{Cd} \\
(\mathrm{mg} / \mathrm{kg}) \\
\end{array}$ & $\begin{array}{c}\mathrm{Cr} \\
(\mathrm{mg} / \mathrm{kg})\end{array}$ & $\begin{array}{c}\mathrm{Cu} \\
(\mathrm{mg} / \mathrm{kg})\end{array}$ & $\begin{array}{c}\mathrm{Ni} \\
(\mathrm{mg} / \mathrm{kg}) \\
\end{array}$ & $\begin{array}{c}\mathrm{Pb} \\
(\mathrm{mg} / \mathrm{kg})\end{array}$ & $\begin{array}{c}\mathrm{Zn} \\
(\mathrm{mg} / \mathrm{kg})\end{array}$ \\
\hline \multirow{3}{*}{$\begin{array}{l}\text { Sediment quality } \\
\text { guidelines of China }{ }^{\text {a }}\end{array}$} & Class I & - & 20 & 0.5 & 80 & 35 & $34^{\mathrm{c}}$ & 60 & 150 \\
\hline & Class II & - & 65 & 1.5 & 150 & 100 & $40^{c}$ & 130 & 350 \\
\hline & Class III & - & 93 & 5 & 270 & 200 & $40^{\mathrm{c}}$ & 250 & 600 \\
\hline \multirow{3}{*}{ The SQGs of US EPA } & Non-polluted & - & $<3$ & - & $<25$ & $<25$ & $<20$ & $<40$ & $<90$ \\
\hline & Moderately polluted & - & $3-8$ & - & $25-75$ & $25-50$ & $20-50$ & $40-60$ & $90-200$ \\
\hline & Heavily polluted & - & $>8$ & $>6$ & $>75$ & $>50$ & $>50$ & $>60$ & $>200$ \\
\hline \multirow{2}{*}{$\mathrm{SQGs}^{\mathrm{b}}$} & TEL & - & 7.2 & 0.68 & 52.3 & 18.7 & 15.9 & 30.2 & 124.0 \\
\hline & PEL & - & 41.6 & 4.2 & 160.4 & 108.2 & 42.8 & 112.2 & 271.0 \\
\hline Background value $^{\mathrm{d}}$ & & 62700 & 10.7 & 0.095 & 59.0 & 21.1 & 27.6 & 21.6 & 64.5 \\
\hline
\end{tabular}

a National Standard of PR China (2002).

b SQGs: sediment quality guidelines for marine ecosystem; TEL: threshold effect level; PEL: probable effect level; ERL: effects range low (Long and MacDonald, 1998).

c Sediment quality benchmark in Hong Kong SAR (EPDHK, 2005).

d Background values in the Yellow River Delta. (China National Environmental Monitoring Center 1990). 
Table 5 The classification of TRI

\begin{tabular}{cc}
\hline TRI value & Pollution level \\
\hline TRI $\leqq 5$ & No toxic risk \\
$5<\mathrm{TRI} \leqq 10$ & Low toxic risk \\
$10<\mathrm{TRI} \leqq 15$ & Moderate toxic risk \\
$15<\mathrm{TRI} \leqq 20$ & Considerable toxic risk \\
$\mathrm{TRI}>20$ & Very high toxic risk \\
\hline
\end{tabular}




\section{Figure captions:}

Figure.1 Location map of the study area and sampling sites. Zones A, B, C and D are the 40-yr-old wetlands, >50-yr-old wetlands, 10-yr-old wetlands, and 30-yr-old wetlands, respectively.

Figure.2 Box plots of enrichment factors (EFs) of heavy metals in the surface soils $(0-20 \mathrm{~cm})$ of >50-yr-old, 40-yr-old, 30-yr-old and 10-yr-old wetlands in the Yellow River Delta. The solid line means $\mathrm{EF}=0.5$, and dash line means $\mathrm{EF}=1.5$.

Figure.3 The toxic unit (TU) of each heavy metal and the sum of toxic units ( $\sum$ TUs) of seven heavy metals in the surface soils $(0-20 \mathrm{~cm})$ of 35 soil samples in four wetlands.

Figure.4 The toxic risk index of 35 soil samples in four wetlands and the contribution ratio of each heavy metal.

Figure.5 The linear relationship be the sum of toxic units ( $\sum \mathrm{TUs}$ ) and toxic risk index (TRI). 


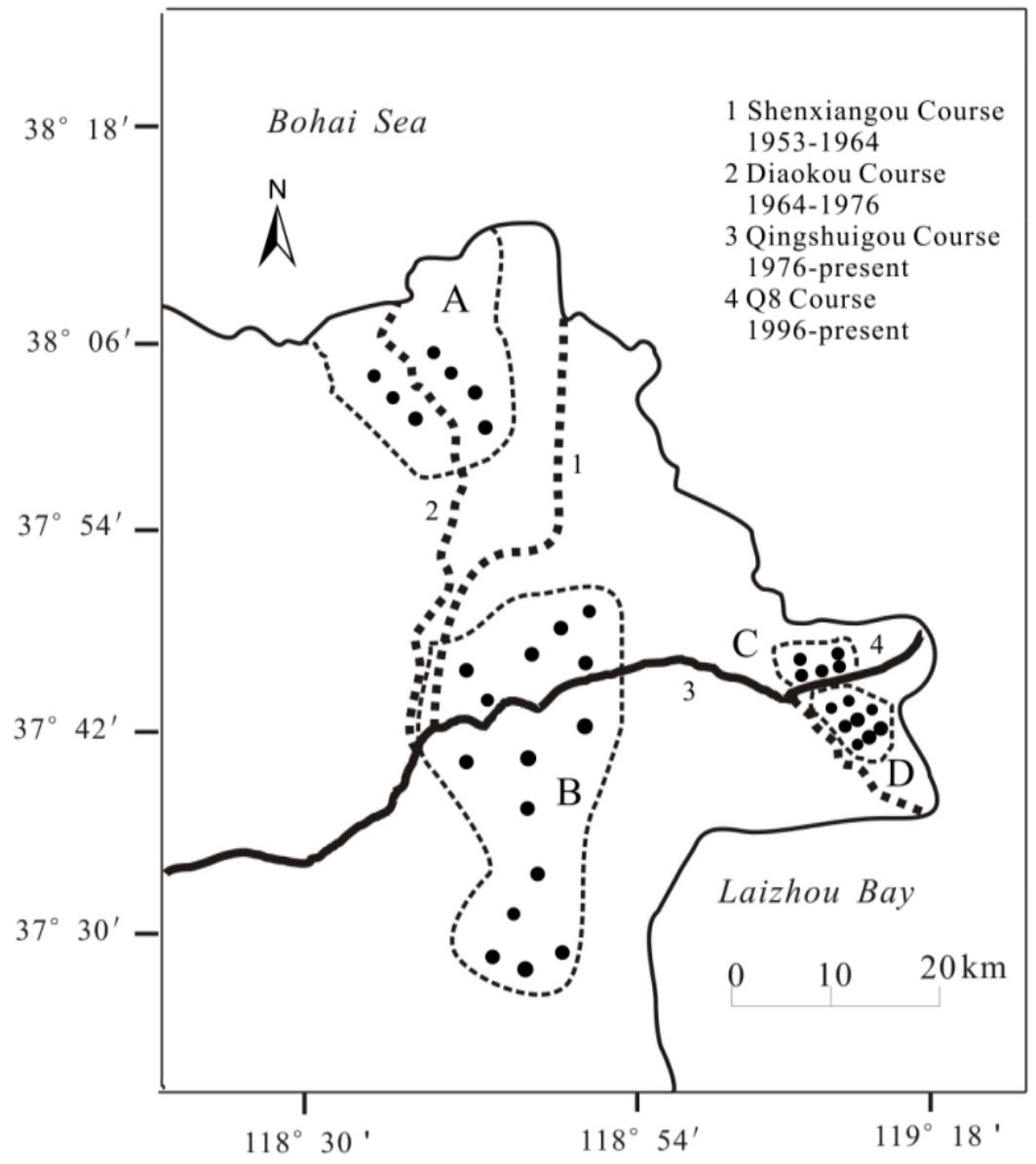

Figure 1 

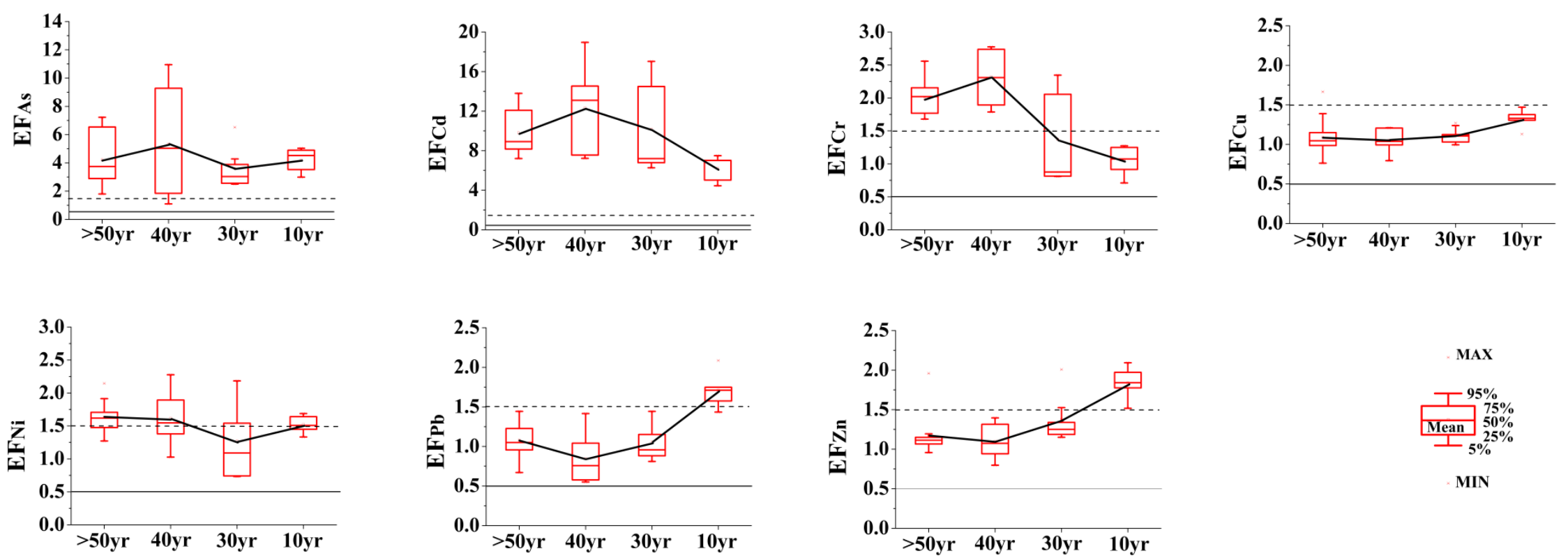

MAX

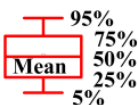

MIN

Figure 2 


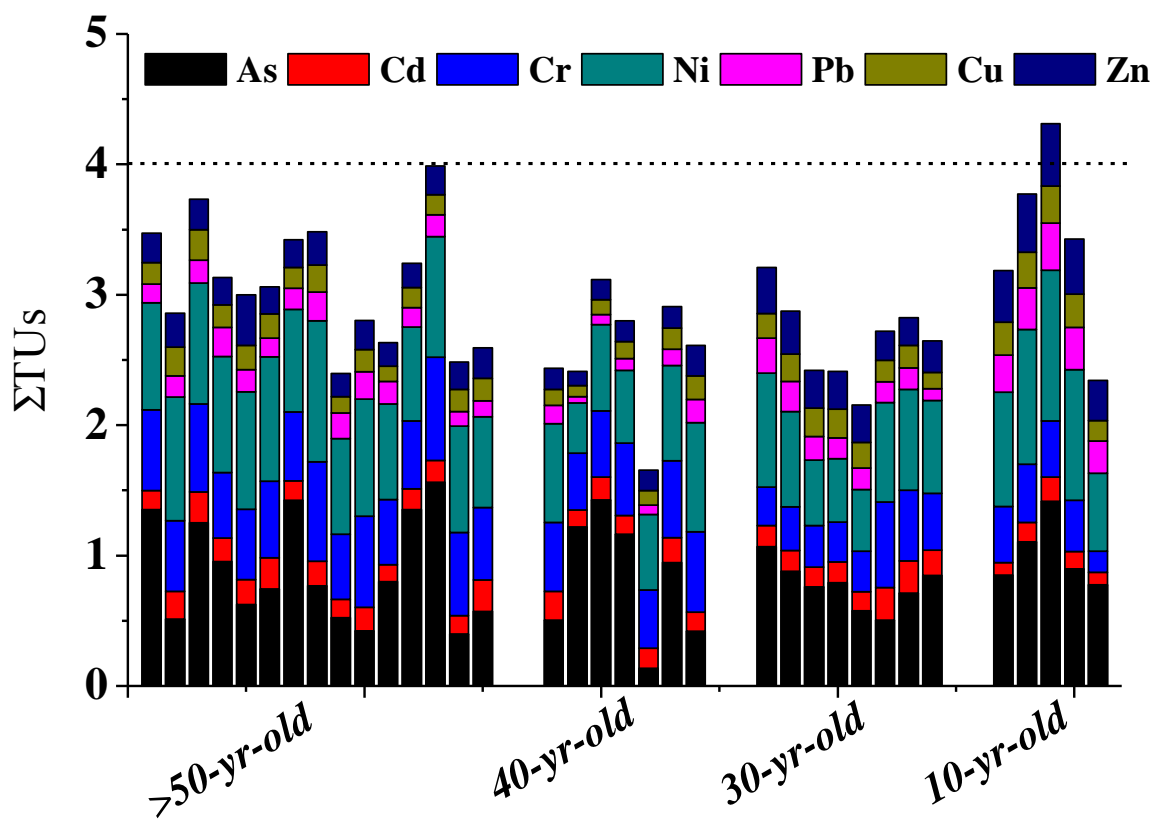

Figure 3 


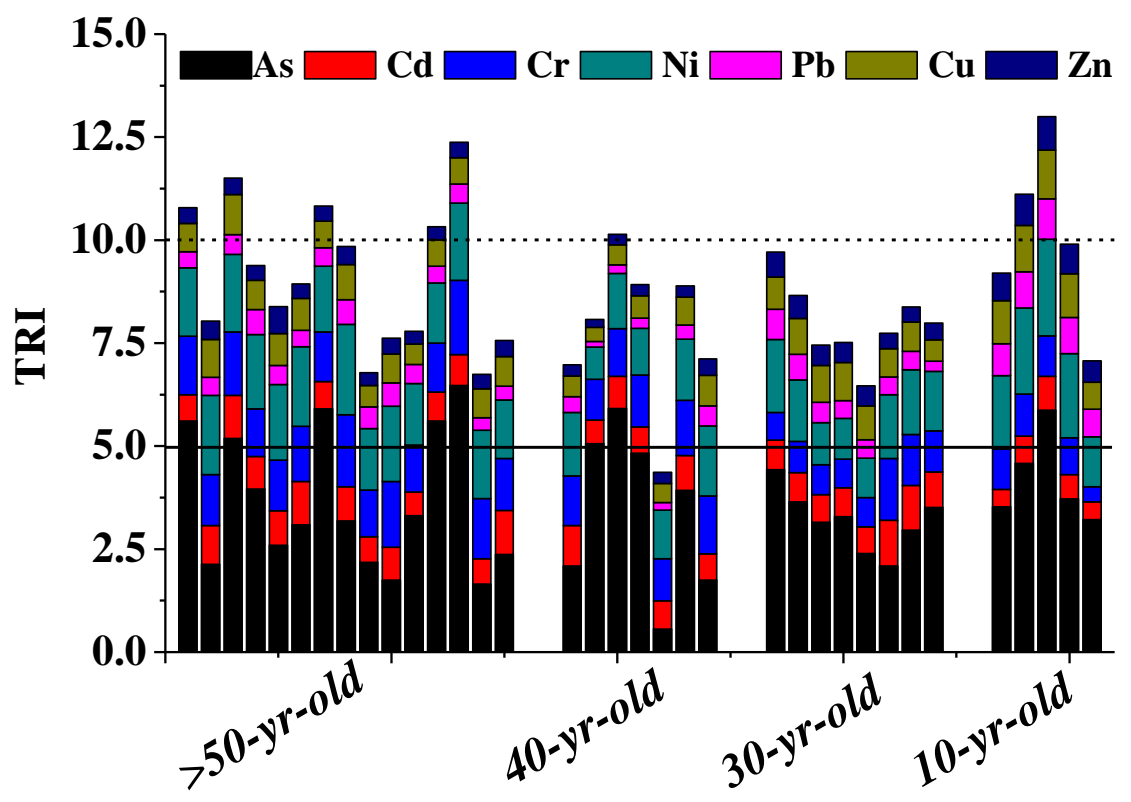

Figure 4 


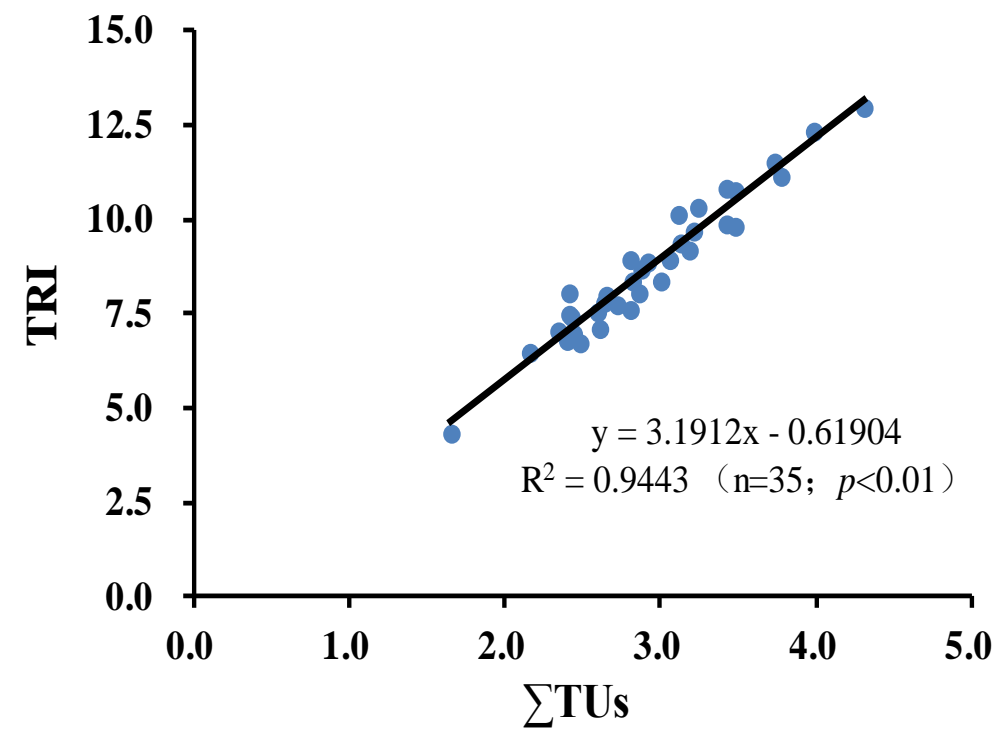

Figure 5 